connected with the absence of the destructive effects which are observed under opposite conditions, it may be fairly inferred that these processes are protective-that is, that although they are themselves constituents of a morbid process, they conduce to the destruction or elimination of the materies morbi. But in the facts before us to-day there is nothing to justify the conclusion that the incorporation of microphytes in cells is the chief or only way in which the human or animal organism exercises its protective influence.

In concluding to-day's lecture with these statements as regards staphylococcus, I must ask you to bear in mind that there are other organisms which stand in the same or in a similar relation to the process of inflammation. Of these I have to-day referred to streptococcus cursorily, as regards which it has been shown by a large body of evidence, clinical and experimental, that its action resembles staphylococcus in most respects. The question of the difference between them has been lately satisfactorily dealt with by MM. Lannelongue and Achard in the research to which I have already referred. The results to which they have come are these: The visceral lesions produced by the chain-coccus differ only in degree-i.e., in their being less intense, from those due to the cluster-coccus. Each is capable of producing osteomyelitis experimentally and may be the cause of io clinically. That two microphytes which are so easily distinguished in the laboratory should be almost undistinguishable in their action is a fact which evidently bears on the view to be taken of the relation between microphyte and its morbific action. This we shall have the opportunity of considering in relation to another phlogogenic microphyte, viz., the lung-cocens, which plays so important a part in several infective inflammations. The main question relating to the etiology of inflammation remains to be discussed. It may, I think, be admitted that either staphylococcus or some similarly endowed anærophyte is the proximate cause of all acute inflammations which are met with in practice. 'Is it the only cause? Or can suppuration be produced by other agencies independently of microphytic intervention? On this question $I$ shall be able to present to you clear evisence in my next lecture.

\section{AN APOLOGY FOR LECTURES.}

SOME REMARKS INTRODUCTORY TO THE FIRST PAIT OF THE COURSE OF LECTURES ON MEDICINE AT THE WESTMINSTER HOSPITAL.

BY OCTAVIUS STURGES, M.D.

RECENTLY, in an evening paper, the St. James's Gazcte, a correspondent wrote: "The London medical schools yesterday opened their doors to students, and forthwith each student's time, for about twelve hours each week, will be occupied by hearing lectures. Will some one of the lecturers explain wby in these days, when books written by the ablest members of the medical profession are within reach of everyone, the students are obliged to spend time in obtaining information by hearing what, I venture to suggest, they could obtain more rapidly and efficiently by reading?" That shall be my text to-day. If the writer's contention be true-and he is not alone in his belief, - this, our first meeting, opens a dreary prospect of misspent time and fatile effort both for you and for me. We may put out of view, indeed, such lectures as are also demonstrations, where the teacher has something to show as well as something to say-lectures on chemistry or practical physiology, for example, their use is obvious. The remarks I have jast read refer to such a course as this we are now commencing, to lectures merely, with no more immediate illustration than the patients in the wards. So limited, let me bry to answer the question, Are lectures-lectures in medicine, let us say - of any use?

There are some lines of defence for lectures which I shall not adopt. Every practice or institution finds defenders so long as it lasts. Slavery and bull-baiting and savage laws, many things which all now admit to be wrong, only ceased to be when the great majority declared against them. They survived for many years the condemnation of all enlightened men. So may it be with lectures. The reading of a well-worn manuscript in a monotonous voice with o ring of interest about it, by a seated professor who never really addressed his audience - a practice commoner thirty years ago than now-was understood to be a perfunctory and ceremonial observance. If it was of use at all, it was useful as a sort of discipline, bringing men together at a certain hour and for a certain time, like roll-call. Precisely so in my time at Cambridge a great Master of Trinity, it was currently reported, used to account morning chapel. In reply to defaulting undergraduates, who pleaded that in the circumstances they found prayer difficult, he would say, "You do not go to pray; you go to be 'marked." I shall not defend lectures on that ground.

The position, I say, is precisely that suggested by obsolete bad laws and cruel sports. Lectures in the past, many of them, are now admitted to have been useless, yet they survived and found defenders; they were, indeed, less cavilled at then than now. What is the proof that the lectures of the present are of any greater service? May it not be that we ourselves are actors and witnesses in a gradual process of transition which will end in the final extinction of formal lectures as a mode of teaching, insomuch that the student of the next generation will look upon us as sufferers under a blind routine in much the same way as we now regard the perfunctory chair lectures of the past?

That there does already exist, and has long existed, a certain feeling or sentiment which is apologetic in regard to formal lectures, if not opposed to them, can hardly be doubted. A movement of that sort, indeed, is so distinct and far-reaching that it has even stirred the General Medical Council. No one can mistake the spirit that breathes in the recommendation of that body that lectures upon any one subject are not to exceed three a week, as well as in the new meaning they have found for the word "practical." This subject of the practice of medicine, for example, that we are now beginning cannotbe discussed, however cursorily, at the rate of three lectures a week in the six months devoted to it. The Medical Conncil is not likely to be openly revolutionary, but their plain hint is that lectures are of little use, except for getting " marked ;" "practical work" is every thing.

Now, against this spirit of the Medical Council, and in answer to the St. James's Gazette correspondent, I would maintain that the requisite information he speaks of is not " to be obtained more rapidly or efficiently by reading than by listening to lectures," and, what is more, that the student knows that it is not. Men come to lecture by choice, and because they find that coming contributes to the im mediate object of their existence-namely, getting through, satisfying the examiners. What is the ground, you will ask, of such dogmatic assertion? It is this. Students, as a general rule, attend many more lectures than they need attend-more, I mean, than the minimum that entitles them to the lecturer's signature. Speaking from an experience of many years, I can \&ay that that is al ways the case. There is, of course, a residuum - a small number who regard "cutting lecture" in the light of an accomplishment. We may safely neglect them, and we do. My point is that the number of those who attend the fewest times possible by the regulations is very small. The great majority come because they like it, and they like it (as could easily be proved by statistics if time served) because, as a matter of fact, it gets them through. Can any evidence in favour of lectures be more "practical" than that?

If you come to think of it, the statement that lectures are no better than books is against reason. I do not stay to speak now of what the lecturer does in collecting and weighing facts and opinions from many sources, and so saving the student's time while helping his judgment. The very same material that the lecturer uses is accessible to others, and he who has the diligence may legitimately prefer to read it for himself and in his own way rather than to hear about it. But the point raised is not met by any considerations of that sort. The contention is this: whatever facts or opinions you hear at a lecture you may read in a book or in books; therefore lectures are useless. I admit the premiss, but altogether demur to the conclusion. Fact for fact, word for word, it is a bold statement that oral learning has no ad. vantage over book learning; for it effaces the Teacher. Now, it so happens that with all the activity of the press, with cheap Jiterature and the multiplication of books and of readers in every department of human knowledge, instruction by the living voice has more than held its own. Lectures have increased in larger measure than books. The lecturer, so far from being effaced, was never in more 
request than now. Oral teaching, indeed, from time immemorial has occupied a distinct place in education, and marks a step in the intellectual growth of everyone, be his profession what it may. The great distinction between school and college-you will not have forgotten it-is thie. At schosl you learn out of a book, repeat the lesson or work the sum; but with the higher teaching comes the lecturer and oral demonstration. That there should be any other mode of education than this, whether general or technical-that from school the learner should pass into the closet, shut to the door, read his books in seclusion, and when perfect come forth to be examined-this has never been quite seriously proposed. When medical students talk so, it is partly their fun, as Charles Lamb said of Coleringe's metaphysics, and partly it is because lectures are so crowded together nowadays that there is small interval between. The modern student, hurried from field to field, has no time to ruminate, and yearns for the green pastures of reading and meditation.

But you will say, May not the book be the exact transcriph of the spoken words? Is it not possible that the lectures themselves-the best of them, in the very phrase of the speakers-should be printed for our use, to be read at leisure and properly digested? Are there no such books available? Yes, there is one, and it was printed nearly fifty years ago. Sir Thomas Watson's Lectures given at King's College in 1837 were published in 1843 , and revised in 1848. Although the boundaries of medicine have vastly extended since that day, these lectures may still be read with pleasure and profit. "Their colloquial and familiar style," as the author himself describes it, is at the same time so graphic as to bring before the reader the very image of disease. But a work of art of this kind does not bear being meddled with, and loses its chief charm in being brought up to date. We have no modern book of lectures on practical medicine, so far as I know, that ventures upon the ground once occupied by Watson and Latham and Todd. And observe that the great merit of these lifelike descriptions is to arouse a desire to see the thing itself. That is the object of lectures now; and although, as I have said, these lectures we are now commencing are without demonstration, yet they point directly to living examples. Our poor discourses are made as good as Sir Thomas Watson's, and better, because we have always at hand appropriate illustrations. We have not, indeed, actually in stock, so to speak, samples of all the diseases we discuss, but we have the elements, or constituent parts, of very many of them. Morbid symptoms and signs in great variety are always on view, and they give life to our meagre descriptions. The wards supplement the lecture room, and no vivid or $\epsilon$ nduring conception of medicine can be got without the help of both.

Two illustrations of this statement strike me at the moment. The lectures of Sir Thomas Watson, owing to their lucidity and avoidance of technical jargon, are favourite reading with intelligent men, and are especially consulted in family sickness. But I hardly ever knew of any lay reader who derived from that matchless book much workable knowledge, while sometimes the views gathered are grotesquely wrong. Again, men of our own profession, many of them of superior intelligence, who have got their practical knowledge mainly from books, and who, as it has happened, have not been in actual touch with disease have not lived with it, their occupation being with science, however nearly allied to medicine, will often display an ignorance on plain matters of illness which to the humblest clinical student is surprising. It is true, no doubt, as I have said, that there is a way of lecturing, common in the past, perhaps not quite obsolete now, which robs discourse of all personality and succeeds in effacing the teacher. But the real, that is the honest, lecturer is a guide; he not only maps out the subject for you, but shows it in its light and shade. The book description is like the rough land or sea map that outlines, but does not further represent it, making no distinction except for size and shape between England and Scotland, Holland and Switzerland. The oral description, fitly illustrated, re sembles the finished model of a country where its physical features are displayed in mountain, valley, and plain. But more than this, the lecturer is your fellow-traveller. You tread with him the path that he has trodden for years, watch his progress, and mark his pace. There are rough places and smooth, stages of the journey to be closely observed, and stages that may be quickly passed over; and he who has been that way before and knows the road will distinguish for you the one from the other, point out hidden and unsuspected difficulties and dangers, and even show where lie the bones of those that have gone before and fallen on the way.

And beyond and above all this, the benefit to be derived from the personality of every true teacher of medicine is to be seen in the temper and the spirit he communicates to his hearers. Partly teacher, partly fellow-learner, he observes with them phenomena of sarpassing interest of which both he and they know but little. The book learner, without the sympathy or the advice of another, fares vari. ously, according to his temperament, but he never fares well. Left to himself in the maze of books and of doctrines, he will sometimes despair of knowing, and sometimes he will force himself into the groove of some narrow system that pretends to know everything. The experienced teacher will sare him from both extremes. Those who disparage and belittle lectures are, I think, of two classes-students who deliberately shut themselves out from their help, and practitioners who in after life, having gathered 2 , wide experience of their own, forget their early obligations. Depend upon it that the question of the use of lectures is one that ought to trouble me raiher than you. The teacher, the interpreter, the go-between, he who should dezcribe and exhibit to you the complex features of disease, camnot wholly fail, he can only by deliberate intent efface hirrizelr. But he must always be conscious of shortcomings and fail habitually to realise his own ideal. If any of you bonest workers come really and seriously to doubt of the good of lectures, be sure that the fanlt is ours, is mine.

\section{A CASE OF}

\section{ACUTE PEREORATING OR ULCERATIVE, AORTITIS IN WHICH THE BAOILLI OF ANTHRAX WERE FOUND.}

By THOMAS OLIVER, M.A., M.D., F.R.C.P.,

PIISICAN TO THE ROYAL INFIRMARY, NEWCASTLE-ON-TYNE; PROYESSOR OF PHISIOLOGY, UNIVERSITY OF DURHAM.

DISEASED CONDITIONS of the thoracic aorta, the result of chronic inflammation or of traumatism, and which end in dilatation of that vessel, are well known to us, but we seldom meeb with cases where the morbid process is of an acute nlcerative character, the termination of which is perforation and sudden death. The case about to be reported is not only unlike any I have hitherto met, bat it differs also from the cases that $I$ have seen recorded; 1 may therefore be pardoned if I detail the history and physical signs at some length.

Joseph $\mathrm{L}_{-}$, aged thirty-six, \& woichmaker, pale, but well nourished, was admitted into the Royal Infirmary, Newcastle-on-Tyne, under my care, suffering from night sweats, extreme nervonsness, great pain in the left side of the chest and down the left arm, of a throbbing, shooting character. Eighteen months ago he had experienced a severe mental shock, which had quite unnerved him. Patient had been on the whole a healthy man untll he was twenty-three years of age, when he had rheumatic fever. That attack must have been a severe one, for it threw him off work for seven months. Previously to this he had been an athlete, and it was to a wetting caught whilst engaged in some athletic sports that be attributed the attack of rheumatic fever. Four years subsequently to this he had another but much milder attack of rheumatic fever, from which he made a good recovery.

When I first saw him there was considerable pulsation of the heart; the apex beat was very diffused; it was felt $\mathrm{rrus} t$ distinctly three inches and a half below the left nipple and one inch external to it. There was also epigasiric pulsation. The area of cardiac dulness was enlarged; extending fria one inch to the right side of the sternum to just beyond the left nipple line, it measured transversely sjx inches and a quarter. Over the aortic area there was heard a doubie murmur. The systolic murmur was carried well up and to the right, whilst the diastolic was carried down the sternam and to the apex. Over the mitral area a loud blowing systolic murmur was heard. This was carried well into the left axilla. The systolic murmur was rough, while the diastolic was rough and cooing. The diastolic murmur was 